\title{
JCAPS
}

\section{TRANSFORMATIONAL LEARNING THEORY: A PEDAGOGICAL FRAMEWORK TO ENCOURAGE SOCIAL PERSPECTIVE TAKING IN FIRST-YEAR STUDENTS IN POST-SECONDARY INSTITUTIONS}

\author{
Joel S. Murphy, Acadia University
}

There has been an increased emphasis for professionals within the field of student affairs to focus on programming that will engage and help support increasingly diverse student populations on (Odağ, Wallin, \& Kedzior, 2016). Bowman (2012) writes: "Many entering college students have had limited opportunities for meaningful interactions and friendships across difference, which further suggests the unique role of college in promoting diversity-related growth" (p.1). Missing within the literature are examples of pedagogical strategies for developing programs that can positively affect inclusivity on post-secondary institution (PSI) campuses. This paper identifies transformational learning theory as a specific pedagogical strategy to help student affairs professionals better support informal firstyear programming. Developing innovative theory-guided programming is necessary to encourage learning and development (Baldwin et al., 2004).

\section{INTRODUCTION}

Student affairs departments are under pressure to provide a positive overall experience for an increasingly diverse student population within post-secondary institutions (PSI) (Bowman, 2012). The struggles of many firstyear students, most commonly individuals attending PSI immediately following graduation from high school, are well documented and researched (Hicks \& Lewis, 2015). PSI contexts represent a microcosm of diversity and a gathering place for students from all backgrounds. These students meet each other in a new context where the focal point is intellectuals and educators stating their diverse and often challenging perspectives and opinions. Students attending PSI will experience diversity in formal settings such as classrooms and informal settings such as living in residence or walking across campus. Inevitably, students will interact with other students, introduce new ideas and perspectives, and challenge students' pre-existing views (Bowman, 2011). The value and importance of helping students engage with the diversity on PSI campuses is an area of needed research and focus. Missing within the literature are examples of pedagogical strategies for developing programs that can positively affect inclusivity on PSI campuses (King \& Magolda Baxter, 2005). The work of student affairs professionals is increasingly identified as paramount for supporting student's academic and personal success. Identifying the need for more intentional and focused programming, this article evaluated relevant literature to identify a pedagogical framework to help inform and shape respective programming (Johnson, 1998). The campus activities of focus for this paper are first-year informal programming and the influence of student affairs professionals adopting a clear pedagogical framework to encourage increased perspective-taking. Through focusing on social perspective-taking, positive engagement with the diversity present on PSI campuses' will be promoted.

\section{Post-Secondary Institution Context}

Student affairs departments support students' academic and personal success through informal and formal learn- 
ing approaches and programs (Bowman, 2011). Specific to engagement with diversity, Gurin et al. (2002), identifies three categories of diversity experiences occurring on PSI campuses. These three categories are: structural diversity (actual representation of diversity within larger PSI community [students, staff, faculty]); classroom diversity (diversity-related course work and co-curricular activities); and finally, the informal interaction (interaction with diverse peers outside of formal programs). Significant informal learning occurs within first-year student socially-focused programming and activities (Frosh week, residence programming, etc.). The developmental stage represented in first-year students presents a unique opportunity for student affairs professionals.

This paper focuses on first-year informal programming as unique experiential educational opportunities and identifies a pedagogical framework to support students' ability to engage with diverse perspectives (King \& Baxter Magolda, 2005). The focus on these types of activities was done in consideration of:

1) Extensive research focused on formal and structured programs such as leadership courses (Astin, 1993), diversity coursework (Pascarella et al., 1996), and service-learning (Niehaus, 2017) and not on more relationally focused, informal programmatic elements (Bowman, 2012).

2) Pedagogical perspective is lacking in the development and design of student affairs programming, especially perspectives accounting for the diverse population participating (Johnson et al., 2017).

3) Informal learning environments (such as programming under review) can offer significant avenues for the development of participants (Dey et al., 2010).

4) First-year student populations are particularly susceptible to intentional development outcomes, which can be foundational for the remainder of their PSI career and beyond (Johnson, Dugan, \& Soria, 2017).

5) Intercultural awareness and the ability to engage with diversity is important for a healthy and positive democratic society (Johnson, 2015).

By developing a theory-guided pedagogically informed programmatic strategy, student affairs professionals can utilize theory to intentionally design programming to evoke institutional loyalty, citizenship in students, support a smooth transition into PSI life, and encourage a more culturally aware and sensitive community (Johnson, 2015).

\section{LITERATURE REVIEW}

\section{Transformational Learning Theory, Scaffolding, and PSI context}

While transformational learning theory has adapted and morphed since first being introduced by Jack Mezirow $(1990,1991)$, it offers a strong pedagogical framework for student affairs professionals to help shape the significantly transitional nature of the first-year student experience. Transformational learning is an adult learning theory that gives a framework to "... Explains the learning process of constructing and appropriating new and revised interpretations of the meaning of an experience in the world" (Taylor, 2008, p. 5). As learners, (first-year students) are examining their perspectives, values, and practice. Student affairs professionals have the opportunity to support positive learning through intentional program design (Bowman \& Brandenberg, 2012). Regardless of process, content, or context, the experiences faced by first-year students align strongly with the altering existence frames of reference identified by Jack Mezirow as foundational for transformational learning to occur. Taylor \& Mezirow (2010) identified six core elements to encourage transformative learning: Individual experience, critical reflection, dialogue, holistic orientation, awareness of context, authentic relationships. Transformational learning theory and the core elements offer a pedagogical framework for evidence-based development of first-year student programming.

By utilizing the theory of scaffolding and transformative learning theory, student affairs professionals can significantly encourage social perspective-taking (SPT) in first-year students. Johnson, Dugan, \& Sofia (2017) support this, stating: "Creating more intentional, scaffolded, structured opportunities for students to reflect on their experiences and learn from others may be an important aspect of transforming practice to increase perspective-taking" (p. 1047). The theory of scaffolding was first introduced by Wood, Bruner, and Ross (1976) and built 
upon the theory of Zone of Proximal Development put forward by psychologist Lev Vygotsky (1978). The theory of scaffolding recognizes the first-year student's developmental stage and the need for intentional support of the development of skills related to the core elements of transformational learning (Wood et al., 1976; Malik, 2017).

\section{Social Perspective Taking and Student Engagement Theory}

The importance of offering programming to encourage first-year student's engagement is grounded in many institutional practices and program calendars. Bowman \& Brandenberg (2012) connect the developmental stage of first-year students with the importance of social perspective-taking, stating: "Because this developmental stage aligns with the traditional age of undergraduate students, college diversity experiences may exert a significant, lasting impact on students' attitudes and values" (p. 180). Social perspective-taking is defined as the capacity to take another person's point of view (Batson, Early, \& Salvarani, 1997) and has been identified by researcher Gehlard (2011) as a "...Process through which a perceiver attempts to discern the thoughts, feelings, motivations, or point of view of one or more targets" (p. 312). SPT is a foundational mechanism that greatly influences students' capacity to engage in greater society and is an important precursor for higher cognitive development (Soria, Werner, \& Nath, 2019). Not all first-year students will participate in formal leadership courses or service-learning projects (Soria, Werner, \& Nath, 2019). However, they will often participate in programming offered on their residence floor or join their first-year intramural team. These informal, experientially based, highly relational programs are significant for first-year students to be exposed to diverse perspectives (Bowman, 2012). Emphasizing engagement with diverse individuals and experiences helps support SPT in first-year students (Astin, 1984). This is beneficial for their time on campus and will enable first-year students to be better able and motivated to participate in diverse, complex communities and social discourses around the topic of diversity (Gurin et al., 2004). The following sections demonstrate how utilizing scaffolding, student engagement theory, and transformational learning theory can support SPT in first-year students.

\section{RECOMMENDATIONS FOR PRACTICE}

The following section outlines the six core elements of transformational learning theory as put forward by Taylor and Mezirow. It articulates the relevance to PSI campuses and the development of SPT. Taylor (2010) state: “... Experiential activities... Help provoke meaning-making among the participants by acting as triggers or disorienting dilemmas, provoking critical reflection, and facilitating transformative learning, allowing learners to experience learning more directly and holistically" (p. 7). The section below establishes the connection between transformative learning theory as a pedagogical framework for student affairs professionals to help first-year students develop their social perspective-taking.

\section{Authentic Relationships}

The first and foundational element of transformational learning is authentic relationships. Taylor (2010) states: "Authentic relationships also allow individuals to have questioning discussions, share information openly, and achieve greater mutual and consensual understanding" (p.13). Applying this core element to programming means focusing on creating spaces for relationships between student affairs staff, student leaders (residence assistants, dons, etc.), and first-year students. This could appear as having student affairs staff spending an increased amount of time within residence building or in high traffic areas on campus, having an open-door policy, or holding monthly gatherings (Gehlbach, 2011). Trust needs to be established in order to enter into a meaningful relationship. The importance of trust in the relationship between diverse peers is the creation of relational capital so that students can ask hard questions, seek understanding, and offer forgiveness.

\section{Individual Experience}

Individual experience takes into account the prior experiences of students and how those helped inform the student's worldview, values, and attitudes. These previous experiences influence the first-year student's ability to engage with new perspectives or concepts which their diverse peers may hold. The foundation of this core element is to raise first-year students' awareness of their own experiences growing up, how that has shaped them, and then to help them realize that their peers may have had entirely different experiences (Mayhem \& Fernadez, 
2007). By running activities that help illuminate the diverse backgrounds of first-year students in a 'controlled' and safe environment, with prompts for critical reflection and helpful dialogue, will aid first-year students as they begin to understand their experiences. Students sharing about their personal experiences will informally occur during programming; however, experiential programs that help illuminate the difference of experiences may help stimulate or disorientate first-year students in understanding the diverse experiences of others (Taylor, 2010). These activities are meant to help create opportunities for students to begin to understand their experience and critically reflect and have positive dialogue with student leaders, student affairs staff, and their peers.

\section{Critical Reflection and Dialogue}

The purpose of grouping the two core elements of critical reflection and dialogue highlights how dialogue acts as a vehicle for critical reflection. Johnson (2015) asserts: "Considering others' perspectives inherently requires dialogue" (p. 688). Facilitating discussions on social and cultural differences, including diversity, religion, social justice, and political affairs, will help increase students' perspective-taking. This can be done by offering times to watch documentaries about particular social topics, followed by intentional \& supported dialogue. Other activities, such as bringing in presenters, which are oriented toward dialogue and less on didactic teaching, will help facilitate first-year students' ability to think critically about diversity and inclusion elements. Asking simplified questions such as "What happens? So, what does that mean? Now what?" (Owen, 2011) is a helpful process and an example of scaffolding. Critical reflection and dialogue present avenues for individual students to reflect and engage with their personal perspectives and offer a means for them to be shared and discussed in safe settings (Johnson, 2015). The importance of relationship is foundational for student leaders and student affairs professionals to encourage critical reflection and meaningful dialogue. It can also be encouraged through a holistic orientation to programming, which is the next core element to promote transformational learning.

\section{Holistic Orientation}

Holistic orientation is referencing the learning and growth of the whole student beyond simply focusing on intellectual development. Howard Gardner (1999) developed the concept of multiple intelligences, which supports and complements this core element. This element intentionally emphasizes the importance of diverse learning styles and draws attention to relational and effective knowing. Acknowledging the diversity in how students engage and learn is important for student affairs professionals. Differing students from different cultural or societal background will learn differently. Holistic Orientation also takes into account the emotional, social, and spiritual aspects of individuals' learning, which holds particular relevance as the development of empathy towards others (Bowman, 2011). Activities that incorporate this element often involve the arts (poetry reading, art night, food-related activity, etc.) and creating spaces for differing cultures to share and for students to emote. Student affairs professionals should also be aware of personal preferences in programming and account for offering programs that differ from their preferences (extrovert vs. introvert).

\section{Awareness of Context}

The final core element to encouraging a transformational learning environment for first-year students is the awareness of context. Turning to Taylor (2010), he states: "Developing an awareness of context when fostering transformative learning is developing a deeper appreciation and understanding of the personal and sociocultural factors that play an influencing role in the process of transformative learning" (p. 11). As students become aware of the differences on their campus, their SPT will increase, as will their understanding of their peers' diverse experiences (Bowman \& Brandenberg, 2012). For student affairs professionals, an awareness of context will help shape the type of programming being offered, when it is offered, and how it is offered. For example, during exams, students will be in heightened levels of stress. Offering activities, such as 'stress busters' or mindful activities, are responsive to those needs and demonstrate an awareness of the PSI context. Another example of being aware of context is if the population of a residence is predominantly caucasian with a minimal number of racially diverse students. The context for misunderstanding and assimilation may be heightened. Student affairs professionals could then be intentional about checking in with the underrepresented students while also offering intentional programming to help the larger student population understand the experience of minority groups. 


\section{CHALLENGES AND LIMITATIONS}

The ability to engage with diverse experiences and individuals reflects high cognitive functions (King \& Baxter Magolda, 2005). This offers a pedagogical framework that should be viewed as a 'starting' point for developing this high cognitive function. More research is needed to understand the role of identity formation, delayed adulthood, previous diversity experiences, and the implications of intentional program development (Bowman, 2012).

Despite the most intentional, innovative, and exceptional programming, engagement is ultimately dependent upon the student. Students allocate their time based on their individual preferences and constraints. Some students enjoy and receive satisfaction from playing video games, while others may prefer to volunteer for a community group. As Pascarella et al. (1996) state: "Institutional policymakers may need to remain mindful of the fact that, although some experiences are particularly influential in terms of enhancing openness to diversity during college, not all students are equally as likely to have those experiences" (p. 192). Individuals of differing cultural backgrounds and other external factors will also respond to programs oriented toward social perspective-taking differently (Johnson, 2015).

\section{CONCLUSION}

The purpose of this paper was to identify a pedagogical framework that would encourage social perspective-taking in first-year students. Utilizing pedagogical frameworks for program development can enhance the program design and help in assessment (Mayhem \& Fernandez, 2007). Through evaluation of research, it was identified that social perspective-taking represents a foundational mechanism for developing an individual's ability to engage with diverse perspectives (cultural, socio-economical, religious, etc.) (Pascarella et al., 1996). Research identifies that interaction with diversity (differing race, cultural background, values) can positively influence perspectives, attitudes, values of students (Johnson, 2015), disrupt cycles of racism (Bowman, 2012), value employers place on 'cultural intelligence' (Odağ, Wallin, \& Kedzior, 2016). Bowman (2012) writes: "By promoting diversity experiences during the college years, college administrators and practitioners can help promote positive outcomes for graduates-and society-well into adulthood" (p. 2). Through a systematic review, this paper identified transformational learning theory as a relevant and applicable pedagogical framework to encourage social perspective-taking in first-year students. With the increasing diversity on PSI campuses, attention to helping students develop the ability to engage with different world views should focus on PSI administrators.

\section{REFERENCES}

Astin, A. W. (1984). Student involvement: A developmental theory for higher education. Journal of College Student Personnel, 25, 297-308.

Astin, A., W. (1993). Diversity and multiculturalism on campus: How are students affected? Change, 25(2), 44-49.

Bowman, N., A. (2011). Promoting participation in a diverse democracy: A meta-analysis of college diversity experiences and civic engagement. Review of Educational Research, 81(1), 29-68.

Bowman, N. A. (2012). Promoting sustained engagement with diversity: The reciprocal relationships between informal and formal college diversity experiences. Review of Higher Education, 36(1), 1-24.

Bowman, N., \& Brandenberger, J. (2012). Experiencing the unexpected: Toward a model of college diversity experiences and attitude change. Review of Higher Education, 35(2), 179-205.

Batson, C. D., Early, S., \& Salvarani, G. (1997). Perspective-taking: Imagining how another feels versus imagining how you would feel. Personality and Social Psychology Bulletin,23(7), 751-758.

Dey, E. L., \& Associates. (2010). Engaging diverse viewpoints: What is the campus climate for perspective-taking? Association of American Colleges and Universities.

Fosnacht, K., McCormick, A., \& Lerma, C. (2018). First-year students' time use in college: A latent profile analysis. Research in Higher Education, 59(7), 958-978. 
Garcia-Ros, R., Perez-Gonzalez, F., Cavas-Martinez, J., \& Tomas, R. (2018). Social interaction learning strategies, motivation, first-year students' experiences, and permanence in university studies. Educational Psychology, 38(4), 451-469.

Gardner, H. (1999). Intelligence reframed: Multiple intelligences for the 21st century. Basic Books.

Gurin, P., Dey, E., Hurtado, S., \& Gurin, G. (2002). Diversity and higher education: Theory and impact on educational outcomes. Harvard Educational Review, 72(3), 330-366.

Gurin, P., Nagda, B.A. \& Lopez, G.E. (2004). The benefits of diversity in education for democratic citizenship. Journal of Social Issues, 60, 17-34.

Gehlbach, H.(2011). Making social studies social: Engaging students through different forms of social perspective taking. Theory Into Practice, 50(4), 311-18.

Hicks, T., and Lewis C. W. (2015). High school to college transition research studies. University Press of America.

Johnson, M., Dugan, J., \& Soria, K. (2017) “Try to see it my way”: What influences social perspective taking among college students? Journal of College Student Development, 58(7), 1035-1054.

Johnson, M. (2015). Developing college students' civic identity: The role of social perspective taking and sociocultural issues discussions. Journal of College Student Development, 56(7), 687-704.

Johnson, S. (1998). The importance of culture for improving assessment and pedagogy. The Journal of Negro Education, 67(3), 181-183.

King, P., \& Baxter M. M. (2005). A developmental model of intercultural maturity. Journal of College Student Development, 46(6), 571-592.

Kuh, G.D. (2009). What student affairs professionals need to know about student engagement. Journal of College Student Development, 50(6), 683-706.

Mayhew, M., \& Fernández, S. (2007). Pedagogical practices that contribute to social justice outcomes. The Review of Higher Education, 31(1), 55-80.

Malik, S. A. (2017). Revisiting and re-representing scaffolding: The Two-gradient model. Cogent Education, 4(1), 13.

Mezirow, J. (1990). Fostering critical reflection in adulthood: A guide to transformative and emancipatory learning (1st ed.). Jossey-Bass.

Mezirow, J. (1991). Transformative dimensions of adult learning (1st ed.). Jossey-Bass.

Niehaus, E. (2017). Building momentum in student engagement: Alternative breaks and students' social justice and diversity orientation. Journal of College Student Development, 58(1), 53-70.

Odağ, Ö., Wallin, H. R., \& Kedzior, K. K. (2016). Definition of intercultural competence according to undergraduate students at an international university in Germany. Journal of Studies in International Education, 20(2), 118-139.

Owen, J. E. (2011) “Considerations of student learning in leadership.” In Komives, S. R., Dugan, J. P., Owen, J. E., Slack, C., and Wagner, W. (Eds.), The handbook for student leadership development. (2nd ed.). Jossey-Bass.

Pascarella, E., Edison, M., Nora, A., Hagedorn, L., \& Terenzini, P. (1996). Influences on students' openness to diversity and challenge in the first year of college. The Journal of Higher Education, 67(2), 174-195.

Reason, R.D. (2011). Encouraging perspective-taking among college students. Education Publications. 76. http:// lib.dr.iastate.edu/edu_pubs/76.

Soria, K. M., Werner, L., \& Nath, C. (2019) Leadership experiences and perspective taking among college students. Journal of Student Affairs Research and Practice, 56(2), 138-52.

Taylor, Edward W. (2008). Transformative learning theory. New Directions for Adult and Continuing Education, 119, 5-15.

Taylor, E. W. (2011). Fostering transformative learning. In Mezirow, \& Taylor (Eds.) Transformative learning in practice: Insights from community, workplace, and higher education, (pp. 3-17). Jossey-Bass.

Wood, D., Bruner, J., \& Ross, G. (1976). The role of tutoring in problem solving. Journal of Child Psychology and Child Psychiatry, 17, 89-100. 